\title{
Proteolytic activity of Clostridium difficile
}

\author{
S. V. SEDDON and S. P. BORRIELLO
}

Microbial Pathogenicity Research Group, MRC Clinical Research Centre, Watford Road, Harrow, Middlesex HA1 3 UJ

\begin{abstract}
Summary. Ten isolates of Clostridium difficile expressing different degrees of toxigenicity and virulence in an animal model were assayed for the production of proteolytic enzymes by various methods. All strains demonstrated some acitivity in one or more of the assay systems. There was no direct correlation between toxigenic status and enzyme production. However, those strains known to be highly virulent in a hamster model were the most proteolytic. The most commonly detected enzyme was cell associated, and its substrate specificity suggested it was a trypsin-like enzyme. Initial purification of the enzyme from strain VPI 10463 gave a $10 \%$ yield with a 14-fold increase in purity. Inhibition studies on this preparation indicated that the enzyme was a thiol protease. The enzyme has $\mathrm{pH}$ and temperature optima of 7.5 and $37^{\circ} \mathrm{C}$, respectively. These characteristics suggest that the enzyme is more related to clostripain, the thiol clostridio-peptidase of $C$. histolyticum, than to trypsin. Whilst the role of this enzyme remains unclear, it is possible that it may be a contributory factor in the virulence of the organism as described for other clostridial infections.
\end{abstract}

\section{Introduction}

Clostridium difficile is now recognised as the major cause of pseudomembranous colitis and is implicated in many cases of antibiotic-associated colitis and diarrhoea. ${ }^{1-3}$ The pathogenicity of the organism has been explained in part by the identification of several known and putative virulence factors-toxin production, ${ }^{4,5}$ adhesion to the gut wall, ${ }^{6}$ expression of fimbriae $^{7}$ and capsule production. ${ }^{8}$ The possible role in pathogenicity of hydrolytic enzymes produced by the organism has been highlighted recently. ${ }^{9}$ However, although protease formation by other anaerobic pathogens has been well documented, ${ }^{10,11}$ there is a paucity of information about the proteolytic properties of $C$. difficile. Furthermore, recent studies on the metabolism and nutritional requirements of $C$. difficile have indicated that the species is asaccharolytic, and, whilst it can ferment free amino acids, the preferred substrates are low-mol.-wt peptides. ${ }^{12}$ Therefore, it is reasonable to hypothesise that $C$. difficile would produce proteases capable of ensuring a supply of peptides suitable for metabolism. The inability to compete for necessary substrates for nutrition may explain in part the phenomenon of colonisation resistance, the breakdown of which is so characteristic of $C$. difficile infections. In this paper we report the results of investigations to detect and identify proteases produced by $C$. difficile.

\section{Materials and methods}

\section{Bacteria and media}

Ten isolates of $C$. difficile (table $\mathrm{I}$ ), described in detail previously, ${ }^{9}$ were maintained by weekly subculture on defibrinated sheep blood $5 \%$ agar (Difco). All isolates were grown at $37^{\circ} \mathrm{C}$ in an atmosphere of $\mathrm{N}_{2}$ $80 \%, \mathrm{H}_{2} 10 \%$ and $\mathrm{CO}_{2} 10 \%$. For the fluorogenic and chromogenic assays, cells were harvested from 48-h cultures in Brain Heart Infusion (BHI) Broth (Oxoid) by centrifugation at $4000 \mathrm{~g}$ for $20 \mathrm{~min}$. The cell pellet was then resuspended in phosphate-buffered saline (PBS) and sonicated on ice in an MSE Soniprep (13 microns; $4 \times 30$ s) until at least $80 \%$ of cells appeared to be disrupted when examined by light microscopy. Both sonicated cell-pellet suspensions and the culture supernates were standardised to a protein concentration of $100 \mu \mathrm{g} / \mathrm{ml}$ by the dye-binding method ${ }^{13}$ before assaying for proteolytic activity. Porphyromonas (Bacteroides) gingivalis strain W83 (a clinical isolate), a known highly proteolytic organism, ${ }^{14}$ was used as a positive control. All assays were performed in triplicate or more frequently.

\section{Plate assay}

Filter sterilised casein (Difco), skimmed milk powder (Oxoid), or gelatin (Sigma) were added to BHI agar to a final concentration of $2 \%$. After inoculation and incubation for 4 days, plates were observed for any clearing before being flooded with a Coomassie 
Blue (Sigma) $0.001 \%$ solution for $5 \mathrm{~min}$. Translucent areas, $>6 \mathrm{~mm}$ diameter, surrounding bacterial colonies were recorded as positive reactions; areas of clearing $<6 \mathrm{~mm}$ or a reduction only in the opacity of the surrounding media were considered weak reactions.

\section{Azo-dye assay}

Cells harvested from sheep blood $5 \%$ agar after anaerobic incubation for $48 \mathrm{~h}$ at $37^{\circ} \mathrm{C}$ were resuspended in PBS to a protein concentration of $100 \mu \mathrm{g} /$ $\mathrm{ml}$. Samples $(5 \mathrm{ml})$ of these bacterial suspensions were added to $5 \mathrm{ml}$ of an aqueous solution containing azocollagen, azoalbumin or azocasein (all $2 \% \mathrm{w} / \mathrm{v}$; Sigma), and incubated aerobically at $37^{\circ} \mathrm{C}$ for $6 \mathrm{~h}$. Dye released from the diazotised proteins was measured spectrophotometrically at $450 \mathrm{~nm}$ as described elsewhere. ${ }^{15} \mathrm{~A}$ positive reaction was recorded for values $>1 \mu \mathrm{g}$ of diazoprotein hydrolysed, a weak result for $<1 \mu \mathrm{g}$ diazoprotein hydrolysed.

\section{Hydrolysis of fluorogenic substrates}

Synthetic fluorescent labelled substrates were used to detect specific protease activities of the test isolates. The substrates employed were: N-Benzoyl-L-arginine7-amido-4-methylcoumarin (BAAMC), a trypsin and papain substrate; L-Lysine-alanine-7-amido-4methylcoumarin (LAAMC), a dipeptidyl aminopeptidase substrate; proline-phenylalanine-arginine-7amido-4-methylcoumarin (PPAMC), a kallikrein substrate; and $\mathrm{N}$-succinyl-glycine-proline-leucine-glycine-proline-7-amido-4-methylcoumarin (SAMC), a collagenase-like peptidase substrate. Reactions were performed in microtitration trays with $20 \mu$ lof aqueous substrate $(4 \mu \mathrm{g} / \mathrm{ml}$; Sigma) and $30 \mu \mathrm{l}$ of sonicated cellpellet suspension or culture supernate. Plates were prepared in duplicate. One set was incubated anaerobically and the other aerobically, for $2 \mathrm{~h}$ at $37^{\circ} \mathrm{C}$, before being examined under UV irradiation $(300 \mathrm{~nm})$; a positive result was indicated by fluorescence. Results were expressed qualitatively as positive, weak or negative.

\section{Hydrolysis of chromogenic substrates}

Enzyme activities were measured quantitatively with chromogenic substrates. The substrates used were: $\quad$ N-CBZ-glycyl-glycyl-L-leucine-p-nitroanilide (GGLN), a subtilisin substrate; N-CBZ-leucine-leucine-glutamine- $\beta$-napthylamide (LLGN), a cationsensitive endopeptidase; $N \alpha$-benzoyl-D,L-arginine- $p$ nitroanilide (BAPNA), a trypsin substrate; and $N \alpha-p$ tosyl-L-arginine methyl ester (TAME), a chymotrypsin substrate. To $1.3 \mathrm{ml}$ of the reaction mixture, containing $50 \mathrm{mM}$ Tris- $\mathrm{HCl}$ (pH 8.5), $20 \mathrm{~mm}$ cysteine hydrochloride and $1.2 \mathrm{~mm}$ substrate, was added $0.6 \mathrm{ml}$ of culture supernate or sonicated cell-pellet suspension. The reaction was followed by monitoring the absorbance at $412 \mathrm{~nm}$ for the $p$-nitroanilide substrates, $380 \mathrm{~nm}$ for the $\beta$-naphthylamide substrates and $340 \mathrm{~nm}$ for the methylester. The amount of chromophore released was determined from its extinction at the appropriate wavelength. Test results were corrected for spontaneous hydrolysis of substrate by replacing the $C$. difficile test sample with buffer.

\section{Preliminary protease purification}

Strain VPI 10463 was cultivated anaerobically in dialysis bags for $48 \mathrm{~h}$ as described previously. ${ }^{16}$ Cells were harvested by centrifugation at $4^{\circ} \mathrm{C}(8000 \mathrm{~g}$ for $15 \mathrm{~min}$ ), washed in PBS and suspended in $10 \mathrm{ml}$ of PBS. This cell suspension was sonicated as described above, passed through a $0 \cdot 22-\mu \mathrm{m}$ filter, and loaded on a $Q$ sepharose FF anion-exchange gel (Pharmacia) fitted in a fast protein liquid chromatography apparatus (Pharmacia). Elution by a $0-1 \cdot 0 \mathrm{M} \mathrm{NaCl}$ gradient in $20 \mathrm{~mm}$ Tris- $\mathrm{HCl}(\mathrm{pH} 7 \cdot 5)$ was performed and 2-ml fractions were collected. All fractions were assayed for proteolytic activity in a microtitration-plate assay, with L-BAPNA as the substrate, as described above. Positive fractions were pooled and loaded on to Mono Q (Pharmacia), a second anion exchange gel column; elution was as described above except that 1-ml fractions were collected and screened for proteolytic activity against $L$-BAPNA.

\section{Protease characterisation}

The substrate specificity of the partially purified enzyme was investigated with the range of chromogenic and fluorogenic substrates described above plus a thiol protease substrate, benzoyl-arginine ethyl ester (Sigma), whose breakdown was followed at $340 \mathrm{~nm}$.

The effect of the addition of various protease inhibitors on the enzyme's ability to hydrolyse the LBAPNA substrate was investigated by adding to the reaction mixture $20 \mu \mathrm{l}$ of a $10 \mathrm{~mm}$ aqueous suspension of inhibitor $10 \mathrm{~min}$ before addition of substrate; the reaction was followed as described above. The inhibitors studied included three serine protease inhibitors-soyabean trypsin inhibitor, $\mathrm{N}-\alpha$-tosyl-Llysine chloromethyl ketone (TLCK) and N-tosyl-Lphenyalanine chloromethyl ketone (TPCK)-and three thiol protease inhibitors - ethylguanidine, ethylalanine and butylamine (all supplied by Sigma).

To investigate the effect of $\mathrm{pH}$ on the enzyme activity, $1 \mathrm{ml}$ of partially purified enzyme was freezedried and $10 \mu \mathrm{g}$ was resuspended in a range of biological buffers (BDH). The effect of $\mathrm{pH}$ on the stability of L-BAPNA was previously determined. The temperature optimum of the enzyme was determined in tests incubated in water baths set at various temperatures, again with L-BAPNA as substrate. 


\section{Results}

\section{Protease activity}

The spectrum of protease produced by $C$. difficile varied between strains. Strains 2B, VPI 10463 and P1 , in particular, possessed a wide range of activities (tables I, II and III), whereas strain DD demonstrated no activity against any of the substrates, except very weak degradation of three of the four chromogenic substrates. There was no correlation between toxigenic status and protease activity. However, strains known to be highly virulent in the hamster model ${ }^{17}$ - strains 2B, P- $1^{17}$ and VPI 10463 -displayed the greatest proteolytic activity.

The substrate-incorporated agar method proved less sensitive than assays with diazotised, fluorogenic and chromogenic substrates. None of the test isolates caused clearing on gelatin plates (table I) but this could in part be explained by the poor sensitivity of this method. However, the skimmed milk plates demonstrated the presence of non-specific proteolytic activities very clearly with translucent zones surrounding bacterial colonies. With diazotised substrates, the two strains that gave positive results in the plate assay for casein degradation were confirmed to give positive reactions and five others were shown to have weak activity (table I). The more globular azoalbumin proved relatively resistant to breakdown (table I). Six of the 10 isolates degraded azocollagen (table I) and the same six isolates also degraded the collagen-like peptidase fluorogenic substrate, SAMC (table II).

Only two isolates, 2B and VPI 10463, readily degraded the dipeptidyl aminopeptidase substrate (LAAMC) (table II); five strains degraded both kallikrein (PPAMC) and trypsin (BAAMC) substrates, and two strains (S-1 and MA) degraded BAAMC but not PPAMC.

Whilst a positive result in tests with the chromogenic substrates indicated that some enzyme activity was present, only values greater than one third of that recorded for $P$. gingivalis $\mathrm{W} 83$ were considered strongly

Table I. Virulence characteristics and proteolytic activity of $C$. difficile isolates and $P$. gingivalis against various substrates

\begin{tabular}{|c|c|c|c|c|c|c|c|c|}
\hline Bacterial strain & $\begin{array}{l}\text { Toxigenic } \\
\text { status }\end{array}$ & Virulence* & $\begin{array}{l}\text { Casein } \\
\text { plates }\end{array}$ & $\begin{array}{c}\text { Skimmed milk } \\
\text { plates }\end{array}$ & $\begin{array}{l}\text { Gelatin } \\
\text { plates }\end{array}$ & Azocasein & Azoalbumin & Azocollagen \\
\hline \multicolumn{9}{|l|}{ C. difficile } \\
\hline $2 \mathrm{~B}$ & + & $\mathrm{H}$ & + & + & - & + & - & + \\
\hline VPI 10463 & + & $\mathbf{H}$ & - & $\mathbf{W}$ & - & W & W & + \\
\hline P-1 & + & $\mathbf{H}$ & - & $\mathbf{W}$ & - & W & - & + \\
\hline Tra $5 / 5$ & + & $\mathrm{L}$ & - & - & - & - & W & + \\
\hline $\mathrm{SC}$ & + & $\mathbf{L}$ & - & - & - & $\mathbf{W}$ & - & - \\
\hline DD & + & $\mathbf{L}$ & - & - & - & - & - & - \\
\hline MA & + & L & - & $\mathbf{W}$ & - & $\mathbf{w}$ & w & + \\
\hline $\mathrm{KN}$ & - & AV & W & - & - & + & W & - \\
\hline M-1 & - & AV & - & - & - & - & W & - \\
\hline S-1 & - & AV & - & + & - & $\mathbf{W}$ & - & + \\
\hline \multicolumn{9}{|l|}{ P. gingivalis } \\
\hline W83 & - & $\ldots$ & + & + & W & + & - & + \\
\hline
\end{tabular}

+ , Positive; W, weak; - , negative; * in hamster model $;{ }^{9,17} \mathrm{H}$, highly virulent; $\mathrm{L}$, less virulent; AV, avirulent.

Table II. Hydrolysis of fluorometric substrates by $C$. difficile isolates and $P$. gingivalis

\begin{tabular}{|c|c|c|c|c|c|c|c|c|}
\hline \multirow{3}{*}{$\begin{array}{c}\text { Bacterial } \\
\text { strain }\end{array}$} & \multicolumn{8}{|c|}{ Hydrolysis of } \\
\hline & \multicolumn{2}{|c|}{ BAAMC } & \multicolumn{2}{|c|}{ LAAMC } & \multicolumn{2}{|c|}{ PPAMC } & \multicolumn{2}{|c|}{ SAMC } \\
\hline & $\mathbf{S}$ & $\mathbf{P}$ & $\mathbf{S}$ & $\mathbf{P}$ & $\mathbf{S}$ & $\mathbf{P}$ & $\mathbf{S}$ & $\mathbf{P}$ \\
\hline \multicolumn{9}{|l|}{ C. difficile } \\
\hline $2 \mathrm{~B}$ & W & + & - & + & - & + & W & + \\
\hline VPI 10463 & W & + & - & + & - & + & + & + \\
\hline P-1 & $\mathbf{W}$ & + & - & $\mathbf{W}$ & - & + & - & $\mathbf{W}$ \\
\hline Tra $5 / 5$ & - & - & - & - & - & - & - & + \\
\hline $\mathrm{SC}$ & - & + & - & - & - & + & - & - \\
\hline DD & - & - & - & - & - & - & - & - \\
\hline MA & - & $\mathbf{W}$ & - & - & - & - & w & + \\
\hline KN & - & - & - & $\mathbf{W}$ & - & - & - & - \\
\hline M-1 & $\mathbf{W}$ & + & - & - & - & + & - & - \\
\hline S-1 & - & + & - & $\mathbf{W}$ & - & - & W & + \\
\hline \multicolumn{9}{|l|}{$P$. gingivalis } \\
\hline W83 & + & + & - & W & - & - & W & + \\
\hline
\end{tabular}

S, supernatant; $P$, cell pellet; +, positive; $W$, weak; - , negative. 
Table III. Protease activity of $C$. difficile isolates and $\boldsymbol{P}$. gingivalis with various chromogenic substrates

\begin{tabular}{|c|c|c|c|c|c|c|c|c|}
\hline \multirow{3}{*}{$\begin{array}{c}\text { Bacterial } \\
\text { strain }\end{array}$} & \multicolumn{8}{|c|}{ Mean (SD) activity ( $\mu \mathrm{mol}$ substrate released $/ \mathrm{min} / \mathrm{mg}$ of protein) with } \\
\hline & \multicolumn{2}{|c|}{ GGLN } & \multicolumn{2}{|c|}{ LLGN } & \multicolumn{2}{|c|}{ BAPNA } & \multicolumn{2}{|c|}{ TAME } \\
\hline & $\mathbf{S}$ & $\mathbf{P}$ & $\mathbf{S}$ & $\mathbf{P}$ & $\mathbf{S}$ & $\mathbf{P}$ & $\mathbf{S}$ & $\mathbf{P}$ \\
\hline \multicolumn{9}{|l|}{ C. difficile } \\
\hline $2 \mathbf{B}$ & $18.8(0.8)$ & $52.8(1.8)$ & $10 \cdot 0(0 \cdot 3)$ & $17.7(0.5)$ & $29 \cdot 6(1 \cdot 3)$ & $178(6 \cdot 4)$ & 0.0 & $0 \cdot 0$ \\
\hline VPI 10463 & $12 \cdot 6(0 \cdot 6)$ & $78 \cdot 0(2 \cdot 3)$ & $8.8(0.2)$ & $15.6(0.4)$ & $28.7(0.9)$ & $154(5 \cdot 8)$ & 0.0 & 0.0 \\
\hline P-1 & $7.0(0 \cdot 1)$ & $33.0(1.0)$ & $11.9(0.2)$ & $28.8(0.8)$ & $33.8(1 \cdot 1)$ & $200(6.0)$ & 0.0 & 0.0 \\
\hline Tra $5 / 5$ & $2 \cdot 0(0 \cdot 1)$ & $6 \cdot 8(0 \cdot 1)$ & 0.0 & $6.0(0 \cdot 1)$ & $12 \cdot 1(1 \cdot 0)$ & $89(1 \cdot 3)$ & 0.0 & 0.0 \\
\hline $\mathrm{SC}$ & $3 \cdot 2(0 \cdot 1)$ & $4.9(0.1)$ & $3.1(0 \cdot 1)$ & $4.7(0.1)$ & $18.0(0.4)$ & $167(11 \cdot 0)$ & 0.0 & 0.0 \\
\hline DD & 0.0 & $8 \cdot 1(0 \cdot 1)$ & 0.0 & $5 \cdot 0(0 \cdot 1)$ & 0.0 & $32(1 \cdot 1)$ & 0.0 & 0.0 \\
\hline MA & $6 \cdot 7(0 \cdot 2)$ & $23.7(0.8)$ & $5.9(0.2)$ & $8.4(0.2)$ & $17 \cdot 5(0 \cdot 9)$ & $87(1 \cdot 8)$ & 0.0 & 0.0 \\
\hline $\mathrm{KN}$ & $5 \cdot 3(0 \cdot 3)$ & $6.9(0 \cdot 1)$ & $1 \cdot 2(0 \cdot 1)$ & $5 \cdot 5(0 \cdot 1)$ & $5.0(0.2)$ & $18(0.9)$ & 0.0 & 0.0 \\
\hline M-1 & $4.7(0 \cdot 2)$ & $14.4(0.3)$ & $6.4(0.3)$ & $7.5(0.2)$ & $28 \cdot 0$ & $137(7 \cdot 5)$ & 0.0 & 0.0 \\
\hline S-1 & $1.4(0 \cdot 1)$ & $7 \cdot 7(0 \cdot 1)$ & $6 \cdot 0(0 \cdot 2)$ & $7 \cdot 0(0 \cdot 2)$ & $27 \cdot 0(1 \cdot 2)$ & $119(8 \cdot 6)$ & 0.0 & $0 \cdot 0$ \\
\hline \multicolumn{9}{|l|}{ P. gingivalis } \\
\hline W83 & $67.5(1.6)$ & $154 \cdot 5(5 \cdot 1)$ & $9 \cdot 8(0.4)$ & $14.9(0.5)$ & $57 \cdot 7(2 \cdot 1)$ & $489(15.6)$ & $27.0(0.98)$ & $53 \cdot 6(1 \cdot 32)$ \\
\hline
\end{tabular}

$S$, supernatant ; $P$, cell pellet.

positive. Performing the assays anaerobically did not appear to increase the levels of detectable activity with any of the substrates. Only two isolates, $2 B$ and VPI 10463, gave high levels of subtilisin activity (GGLN; table III). $P$. gingivalis W83 possessed only low levels of a cation-sensitive endopeptidase and $C$. difficile strains 2B, VPI 10463 and P-1 demonstrated greater activity against this substrate (table III). Trypsin-like activity was quite widely detected, though only three strains (2B, SC and P-1) gave strongly positive reactions, and two strains, $D D$ and $K N$, showed very low activity (table III). However, levels of trypsin-like activity were high for five other strains even in culture supernates (2B, VPI 10463, P-1, M-1, $\mathrm{S}-1)$. None of the strains tested proved capable of degrading the chymotrypsin substrate TAME.

In general, greater activity was detected in the resuspended pellet samples than in the culture supernates when assayed with either fluorogenic or chromogenic substrates.

\section{Protease purification}

Purification of the predominant protease yielded material with a 14 -fold increase in purity and a $10 \%$ yield. This purified material readily degraded thiolcontaining substrate (previously untested in this study), trypsin substrates and, to a lesser degree, the subtilisin substrate; other substrates were unaffected. Activity against the trypsin substrate, BAPNA, was inhibited by ethylamine, butylamine, ethylguanidine and TLCK, but not by TPCK or soyabean trypsin inhibitor. The optimal $\mathrm{pH}$ and temperature of this enzyme activity were 7.5 and $37^{\circ} \mathrm{C}$ respectively (figure).

\section{Discussion}

A wide range of host, dietary and microbial proteins are potentially available as substrates for bacteria in the human colon. Recent investigations have revealed the asaccharolytic nature of $C$. difficile and the possible requirement for small peptides for metabolism. ${ }^{12}$

Our results show clearly that $C$. difficile has some proteolytic activity. Generally, protease activity appeared to be cell associated with only limited amounts detectable in culture supernates. The most commonly produced protease has substrate specificities similar to mammalian trypsin and bacterial subtilisin enzymes, with seven of the 10 test isolates degrading, to some degree, both BAAMC and BAPNA substrates.

The production of proteases by this organism could be important in releasing suitable substrates from available protein sources for metabolism. Furthermore, proteolytic activity has been linked to pathogenicity in other clostridia. ${ }^{10}$ These proteolytic enzymes, together with other hydrolytic enzymes already described for this organism, ${ }^{9}$ may be involved in host
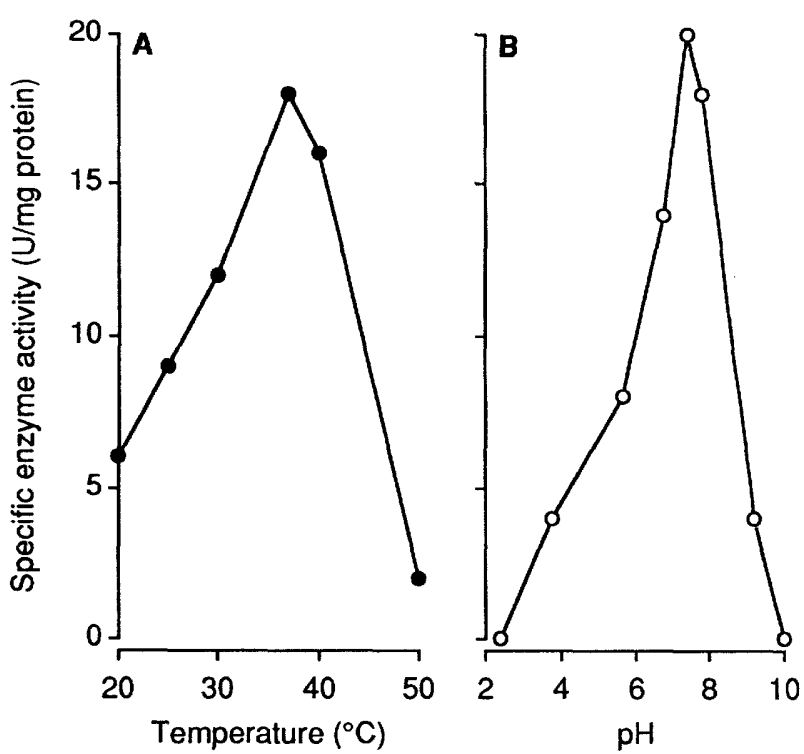

Figure. Temperature and $\mathrm{pH}$ optima of purified protease activity. One Unit $(U)=$ amount of enzyme required to release $1 \mu \mathrm{mol}$ of trypsin substrate (BAPNA) $/ \mathrm{ml} / \mathrm{min}$. 
tissue breakdown. Collagenase activity could clearly be a major contributory factor to such tissue breakdown, and results obtained in this study with a synthetic collagenase substrate confirm results, already published, obtained with native collagen. ${ }^{9}$ That the organism appears to be incapable of breaking down the more globular protein albumin is of interest, as it has been suggested that serum albumin accumulating in the gut due to the activity of $C$. difficile toxin A may compete with toxins A and B for host proteases and thus protect the toxins from degradation. ${ }^{18}$

Recent evidence indicates that toxin $\mathrm{A}$ of $C$. difficile is produced in a partially inactive form that has cytotoxic activity but lacks haemagglutinating activity. ${ }^{8,19}$ The possession of trypsin-like enzymes by $C$. difficile could account for this activation. It is also of interest that none of the strains demonstrated any chymotrypsin activity which would degrade toxins A and $B{ }^{20}$ It is possible that the expression of these proteases and the degree of toxin production, or protoxin activation, or both, might be linked, as has been speculated for $C$. botulinum. ${ }^{21}$ Furthermore, whilst no relationship was apparent between toxigenic status and protease expression by the test isolates, those strains known to be more virulent in the hamster model ${ }^{17}$ were the most proteolytic. These results are

\section{References}

1. George RH, Symonds JM, Dimock F et al. Identification of Clostridium difficile as a cause of pseudomembranous colitis. Br Med J 1978; 1 : 695.

2. Larson HE, Price AB, Honour P, Borriello SP. Clostridium difficile and the aetiology of pseudomembranous colitis. Lancet 1978; 1 : 1063-1066.

3. Borriello SP, Larson HE. Antibiotics and pseudomembranous colitis. J Antimicrob Chemother 1981 : 7 Suppl A: 53-62.

4. Taylor NS, Thorne GM, Bartlett JG. Comparison of two toxins produced by Clostridium difficile. Infect Immun 1981; 34 : 1036-1043.

5. Lyerly, DM, Krivan HC, Wilkins TD. Clostridium difficile: its disease and toxins. Clin Microbiol Rev 1988; 1 : 1-18.

6. Borriello SP, Welch AR, Barclay FE, Davies HA. Mucosal association by Clostridium difficile in the hamster gastrointestinal tract. J Med Microbiol 1988; 25: 191-196.

7. Borriello SP, Davies HA, Barclay FE. Detection of fimbriae amongst strains of Clostridium difficile. FEMS Microbiol Lett $1988 ; 49$ : 65-67.

8. Borriello SP, Davies HA, Kamiya S, Reed PJ, Seddon S. Virulence factors of Clostridium difficile. Rev Infect Dis 1990; 12 Suppl 2: S185-S191.

9. Seddon SV, Hemingway I, Borriello SP. Hydrolytic enzyme production by Clostridium difficile and its relationship to toxin production and virulence in the hamster model. $J$ Med Microbiol 1990; 31: 169-174.

10. Steffen EK, Hentges DJ. Hydrolytic enzymes of anaerobic bacteria isolated from human infections. J Clin Microbiol $1981 ; 14: 153-156$

11. Maclennon JD. The histotoxic clostridial infections of man. Bacteriol Rev 1962; 26: 177-276.

12. Seddon SV, Borriello SP. A chemically defined and minimal medium for Clostridium difficile. Lett Appl Microbiol 1989; 9: 237-239.

13. Bradford M. A rapid and sensitive method for the quantitation in keeping with observations previously reported for other hydrolytic enzymes produced by these isolates. ${ }^{9}$

The substrate specificity of the partially purified protease confirmed the trypsin-like nature of the most prominent protease. However, the inhibition studies did not confirm this hypothesis but suggested, instead, that the protein was a sulph-hydrol enzyme. Therefore, it is possible that this enzyme could be similar to the clostridio-peptidase, clostripain, produced by $C$. histolyticum. ${ }^{22}$ This enzyme cleaves the carboxy peptide bond of arginine, similar to the action of trypsin, but is a sulph-hydrol protease rather than a serine protease, and, as such, is not inhibited by soyabean trypsin inhibitor or TPCK, but is inhibited by TLCK, ethylamine, butylamine and ethylguanidine. ${ }^{23}$ The $C$. difficile protease displays a very similar inhibition pattern. Furthermore, the temperature and $\mathrm{pH}$ optima are similar to those reported for clostripain. ${ }^{23}$ Clearly, further work is necessary to fully purify and characterise this enzyme.

In view of the role in the aetiology of disease of proteolytic enzymes produced by other clostridia, it is possible that the proteases produced by $C$. difficile may similarly be a contributory factor to their virulence in man.

of microgram quantities of protein utilizing the principle of protein-dye binding. Anal Biochem 1976; 72: 248-254.

14. Van Steenbergen TJM, de Graaff J. Proteolytic activity of black pigmented bacteroides strains. FEMS Microbiol Lett 1986; 33: 219-222.

15. Gibson SAW, Macfarlane GT. Studies on the proteolytic activity of Bacteroides fragilis. J Gen Microbiol 1988; 134 : 19-27.

16. Kamiya S, Reed PJ, Borriello SP. Analysis of purity of Clostridium difficile toxin A derived by affinity chromatography on immobilized bovine thyroglobulin. FEMS Microbiol Lett 1988; 56: 331-336.

17. BorrielloSP, Ketley JM, Mitchell TJ et al. Clostridium difficilea spectrum of virulence and analysis of putative virulence determinants in the hamster model of antibiotic-associated colitis. J Med Microbiol 1987; 24: 53-64.

18. Corthier G, Muller MC, Elmer GW, Lucas F, Dubos-Ramare F. Relationship between proteolytic activities, and production of toxin A during Clostridium difficile induced cecitis in gnotobiotic mice. In: Dougherty SH et al. (eds) Microecology and therapy, vol 19. Herborn-Dill, Institute for Microecology. 1990; 217.

19. Kamiya S, Borriello SP. A non-haemagglutinating form of Clostridium difficile toxin A. J Med Microbiol 1992; 36 : 190-197.

20. Lyerly DM, Carrig PE, Wilkins TD. Susceptibility of Clostridium difficile toxins $\mathrm{A}$ and $\mathrm{B}$ to trypsin and chymotrypsin. Microb Ecol Health Dis 1989; 2: 219-221.

21. Patterson-Curtis SI, Johnson EA. Regulation of neurotoxin and protease formation in Clostridium botulinum Okra B and Hall A by arginine. Appl Environm Microbiol 1989; 55 : 1544-1548.

22. Mitchell WM, Harrington WF. Clostripain. In: Boyer PD (ed) The enzymes, vol 3. New York, Academic Press. 1971: 699-719.

23. Mitchell WM, Harrington WF. Purification and properties of Clostripeptidase B (Clostripain). J Biol Chem 1968; 243: 4683-4692. 